\title{
Two Summary Tablets of Balag̃ Compositions with Performative Indications from Late-Babylonian Ur
}

\author{
by Uri Gabbay - Jerusalem and Sam Mirelman - London
}

The tablets BM 113931 and BM 113940, published here, come from Hall's excavations at Ur and were included in Geller's $(2005,98)$ catalogue of the LB literary tablets of this group. ${ }^{1}$ The tablets preserve incipits and extracts of the sequences of sections of the Balag dutu-gin ${ }_{7}$ è-ta and the Balag̃ ukkin-ta eš bar til-1a. Both tablets are written with large script and dividing lines between the various incipits and extracts, and are very likely to have been written by the same scribe.

The tablets contain some syllabic writings and glosses (such as ú-mu-unumun in BM 113931, l.e., r.1), as well as peculiar writings, which differ from the version known from other manuscripts of these Balag̃s. These writings may serve as indications for the purpose for which the tablets were copied, namely, for the actual pronunciation during the cultic performances of these Balag̃s. Like other LB tablets containing Balag̃s and Eršemas, BM 113931 and BM 113940 contain many indications related to their musical performance (see below).

1 Tablet measurements: BM 113931 (1919-10-11, 21): $10.4 \times 7.6 \mathrm{~cm}$, BM 113940 (1919-10-11, 30): $8.6 \times 4 \mathrm{~cm}$. We thank the trustees of the British Museum for permission to publish these tablets and Anne Löhnert for reading the article and suggesting many improvements. We are also grateful to Walther Sallaberger for his useful remarks. There is no exact find spot for these tablets, but since much of Hall's excavations took place at the areas in the vicinity of the Eg̃išnugal temple, it is possible that the tablets stemmed from a library in the temple or its surroundings. For Hall's excavations at Ur, especially in building "B" located to the south-east of the Eg̃išnugal temple, see Hall (1923, 181-188) (we thank C. Walker for the reference to this article). Note that according to Jursa (2005, 137), some archival texts from Ur excavated by Hall belonging to the 1919-10-11 collection (as our tablets), can be dated to the reign of Darius, and that an institutional origin would seem possible for some of them (another group of tablets which was recorded by Hall to be excavated in building "B" stems from the NA period, see Hall 1923, 186; Hall 1930, 164-166; Jursa 2005, 137). Another LB Balag tablet from the same group, BM 113930 (1919-10-11, 20) (// CLAM 229-230: a+126-146, 232-233: a+208-219), preserves a colophon naming the kalu Šamaš-ahhēe-iddina. Note the archival text BM 113957 (1910-10-11, 47) cited by Jursa $(2005,137, \mathrm{n} .1065)$, which deals with the lilissu, an instrument which is connected to kalutu and the performance of Emesal prayers. 
Both BM 113931 and BM 113940 name Eg̃išnugal of Ur in the concluding line of the Balag̃ (before the Eršema), instead of the expected Ekur and Ezida respectively. This local phenomenon of replacing a temple name in the text with the local temple is known from other LB tablets (see Gabbay, forthcoming a). ${ }^{2}$

BM 113931 and BM 113940 belong to a type of tablet which can be termed "summary tablets" or "compendia."3 Since Bala g̃ compositions are very long and are usually spread over several tablets, attempts were made to condense an entire composition (or even several compositions) into one tablet by means of extracts and incipits. There may have been a variety of purposes for this. It could have been for didactic reasons or for performative reasons (the latter indicated by the syllabic spellings and musical indications seen on some of the tablets). ${ }^{4}$

\section{BM 113931}

The tablet BM 113931 contains incipits and extracts of the sequence of sections of the Balag̃ dutu-gin ${ }_{7}$ è-ta, including the Eršema ù-1i-1i en zu sá mar-mar, known to be paired with this Balag̃ according to the Nineveh kalutu catalogue, ${ }^{5}$ ritual texts, ${ }^{6}$ and manuscripts of this Balag which contain this Eršema. ${ }^{7}$ The Balag was recently treated anew by Löhnert (2009), focusing on its OB version. The tablet BM 113931 may further facilitate the reconstruction of the Balag dutu-gin ${ }_{7}$ è-ta in the first millennium.

2 For a similar phenomenon, see BaM Beih. 2, 21, which names É re-eš in this formula at the end of the Balag̃ en zu sá mar-mar (while this Marduk Balag̃ names Esag̃il in the Babylonian canonical tradition preserved in K.5160+, see Gabbay 2007b, 301-302).

3 The designation "compendium" is loaned from the term given by Maul (1994, 203-216) to summary tablets of Namburbi rituals.

${ }^{4}$ Other examples of such compendia are: KAR $99+$ KAR $305+$ VAT 10553 (Bala $\tilde{g}$ nir-g̃ál lú è-NE, cf. Gabbay 2007b, 480-490), SBH 35 + CTMMA 2, 2 (Balag̃ abzu pe-el-1á-àm, cf. Gabbay 2007b, 182), TCL 6, 55 (= TCL 16, 41) (probably Bala g̃ am-e a maš-a-na), perhaps BaM Beih. 2, 21 (Balag̃ en zu sá mar-mar), and possibly A.3513 ("Chicago catalogue," Gabbay 2007a, 86-97. It is possible that this is not a catalogue of the various tablets of the Balag̃s listed in it, but actually a compendium summarizing the incipits of the sequence of the various sections of these Balag̃s. However, the sequence of incipits does not entirely correspond to the known sequence of sections of some of these Balag̃s, and thus, it is not certain whether this is a compendium tablet or a catalogue, cf. Gabbay 2007a, 88-89 with n. 8).

$54 \mathrm{R}^{2}, 53+$, i-ii 5.

${ }^{6}$ Maul 2000, 403: 10'-11'; RitAcc. 40: 6-7 (see Linssen 2004, 293; Ambos 2004, 178).

7 TCL 6, 56 and SBH 40 (Gabbay 2007b, 228-240). 


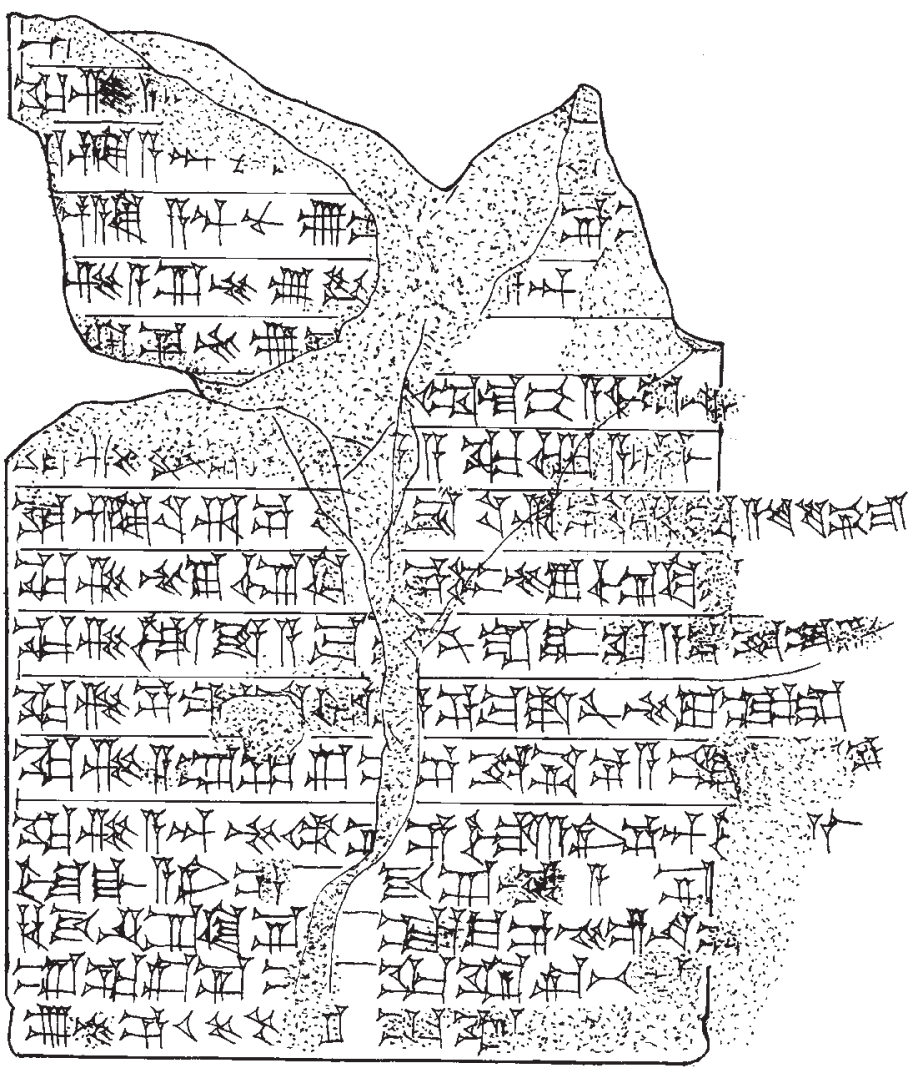

Fig. 1: BM 113931 obv.

Transliteration

obv.

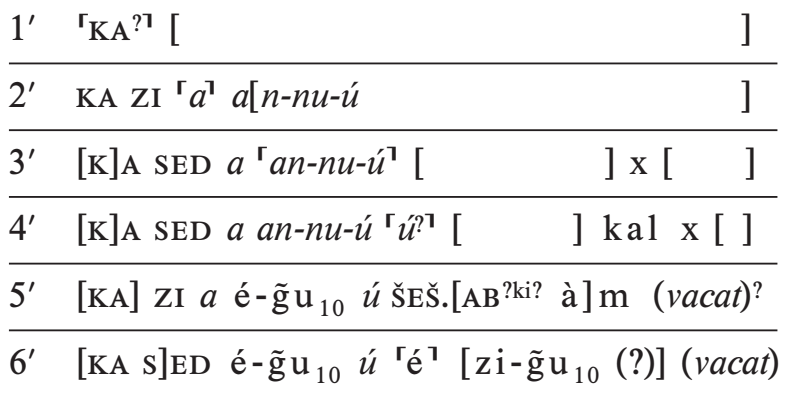




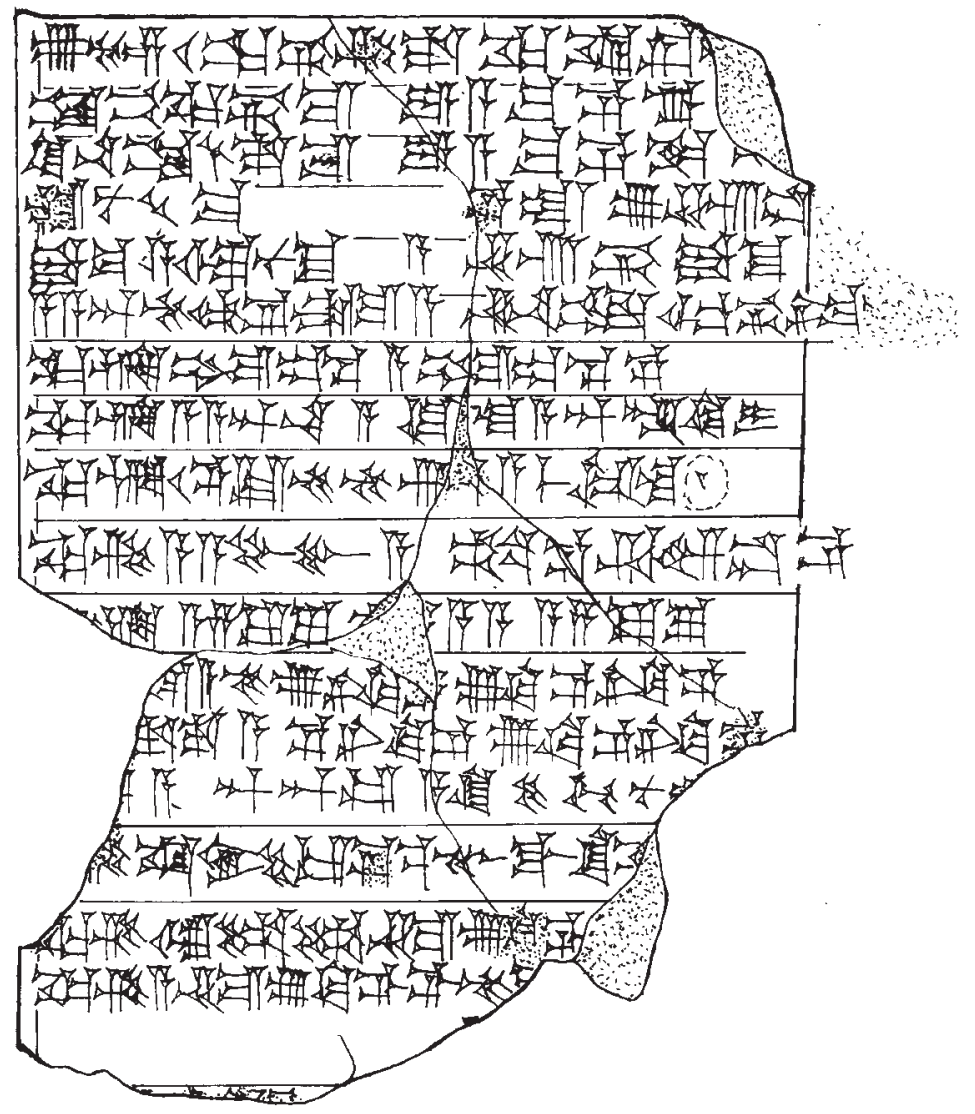

Fig. 1: BM 113931 rev.

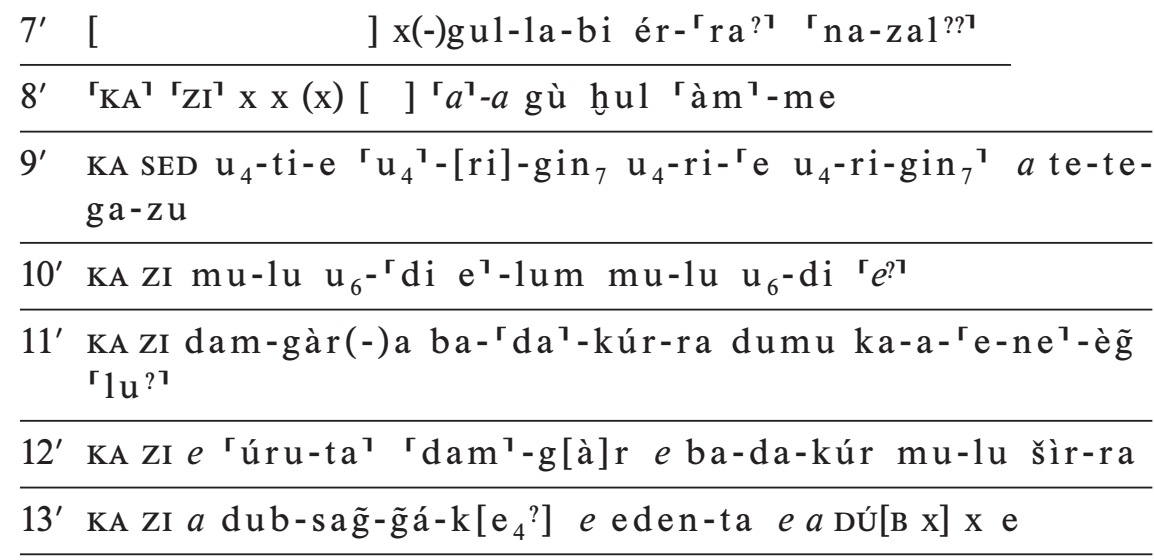


14' KA ZI $a$ dmu-ul-1í[1] $e$ dam-a-ni $e$ dni[n-lí]1-lá

$15^{\prime}$ nin gal-a-ni ' $e^{\top}$ gašan é- ${ }^{\top} \mathrm{mahb}^{\top}-\mathrm{a}-\mathrm{ke}_{4}$

$16^{\prime}$ kù gašan nibruki-ke ${ }_{4}$ šìr-šè $e$ mu-un-na-a[b-bé]

$17^{\prime} \mathrm{dub}-\mathrm{sa} \tilde{\mathrm{g}}-\tilde{\mathrm{g} a ́}-\mathrm{ke}_{4}{ }^{\mathrm{r}} e^{? ?} \mathrm{ka}-\mathrm{na} \tilde{\mathrm{g}}-\tilde{\mathrm{g} a ́ ~ t i l-~}{ }^{\mathrm{\top}} 1 \mathrm{a}^{\top}$

1.e. ú-mu-un!(“E”) umun kur-kur-[r]a ka-na g (vacat)

\section{(bottom)}

rev.

1 ú-mu-unumun du $u_{11}-g a$ zi-da ka-nag̃-ǵá ti[1-la]

2 è $\tilde{g}(-) b i(-) \mathrm{du}_{11}-\mathrm{ga}-\mathrm{zu}$ ia $a$ ba-e-dir-[dir]

3 ki na-ág $\tilde{g}-\mathrm{ku}_{5}-\mathrm{da}-\mathrm{zu}$ ia $a$ ba-e-dè- ${ }^{\top} \mathrm{til}^{\top}$

4 'sipa $^{\top}$ nu-GAM-ma e-zé $u ́$ en-nun-gub

$5 \mathrm{su}_{8}$-ba $a$ ù nu-ku $a$ en-nun-ga $\mathrm{su}_{8}$-tus

6 a-a dmu-ul-líl úru-zu-a en-na dúb-sig ${ }_{5}$-ga-ni ba-a[n-gub]

7 KA SED lugal abzu si a lugal abzu si $e$ (vacat)

8 KA SED $a-a$ AN.NA $a \mathrm{ki}^{?}-\mathrm{la}(-) \mathrm{àm}{ }^{\mathrm{d}+\mathrm{e}} \mathrm{n}-\mathrm{ki} i$

9 KA SED umun-e $\mathrm{du}_{5}-\mathrm{mu}-\tilde{\mathrm{g}} \mathrm{u}_{10}$ nun- ${ }^{\top} \mathrm{na}^{\top} a$ me(-)el-1a (ras.)

10 KA ZI a-a bu-bu $a \mathrm{gu}_{4}$-ud-r $\mathrm{e}^{\mathrm{T}}-\mathrm{re}$ im-DU $e$

11 [KA] SED a-za-1u-1u ' 'ú? [(x)] ' $a^{? ?} a-a$ a-za-lu-1u

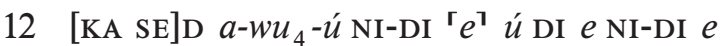

13 [ $\mathrm{d}] \mathrm{a}-\mathrm{da}$ a $e$ NI-DI $e \dot{u}$ DI $e$ NI-DI ${ }^{\top} e{ }^{\top}$

14 [ ] x A AN ${ }^{\mathrm{d} u r a s ̌ ~} a$ ki še-gu-nu-r[a]

15 [KA Z]I šùdu šÈM še-eb é-g̃iš-nu ${ }_{11}$-gal ki N[E-en-gi $\left.i_{4}-g i_{4}\right]$

16 KA ZI ù-1i-li en zu $u^{\mathrm{I}} \mathrm{sá}^{\top} \operatorname{mar}-[\mathrm{mar}]$

17 KA ZI $a$ en zu ú sá mar-mar mu-1[u?? ]

18 (vacat) $\quad \mathrm{x}[$

$19[$ [ ] x x (x) [

(rest broken) 


\section{Notes}

$5^{\prime}$. The restoration $\breve{S} \breve{S}^{-}\left[\mathrm{AB}^{\mathrm{ki}}\right]$ is hypothetical, but would perhaps fit the mention of Ur in a different section of this Balag̃ (Löhnert 2009, 264: 1, see note to line $7^{\prime}$ below).

$6^{\prime}$. The restoration é $-\tilde{g} \mathrm{u}_{10}$ ú é $\left[\mathrm{zi}-\tilde{\mathrm{g}} \mathrm{u}_{10}\right]$ is very uncertain. No such incipit is preserved, but it is possible that the obverse of the unpublished tablet BM 50746 contained this section, where the phrase é $\mathrm{zi}-\tilde{\mathrm{gu}}{ }_{10}$ is repeated several times. The text is almost identical to a section from the Balag̃ a-še-er $\tilde{g} i_{6}$-ta (Black 1985, 21: $135 \mathrm{ff}$.; CLAM 707: a+42ff.),

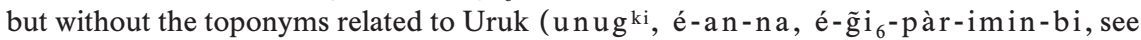
Black 1985, 122: 145-146; CLAM 707: a 52-53), which ae expected to be found in an Inana litany and not in the Enlil litany of our Bala g̃, but, cf. note to line 7 below.

$7^{\prime}$. The last sign (zal) is very uncertain. It may actually be the sign A covered with scratches. As to the identification of this line, the phrase gul-la-bi ér-ra appears as part of an incipit of a section belonging to the OB version of the Balag̃ dutu-gin ${ }_{7}$ è-ta: úriki gul-1a-gin 7 ér-ra mu-ni-in-zal (Löhnert 2009, 264: 1, 'OB Kirugu 2'). It is also very similar to the incipit of a section of the Balag̃ a-še-er $\tilde{g} i_{6}$-ta (Black 1985, 21: $135 \mathrm{ff}$; CLAM 707: a+42 ff.). It is possible, that the obverse of BM 50746 mentioned in note to line $6^{\prime}$ actually belongs to this incipit and not to the previous one, as supported perhaps by BM 50746: 1': x ki-nim ú-ri(-)x [ ], which would correspond to the mention of Ur in the OB incipit or to ŠEš (perhaps to be read ùri in the parallel section of the Balag̃ a-še-er $\tilde{\mathrm{g}} \mathrm{i}_{6}$-ta, cf. Black 1985, 21: 135), i.e., Akkadian urinnu.

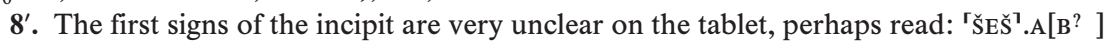
or: $\mathrm{x}^{\mathrm{r}} \mathrm{e}^{? 7} \mathrm{x}$. This section is preserved in the OB version of the Balag ${ }^{\mathrm{d}} \mathrm{u}$ tu $-\mathrm{gin}_{7}$ è $-\mathrm{ta}$ (VS $2,7+13$ and VS 2, 5) and in the form of an extract in UET 6/2, 204: 8-14 (Löhnert 2009, 299-301: 1-18, 'OB Kirugu 3'). The reconstruction of the section was discussed extensively by Löhnert $(2009,294-296)$. The OB section is not preserved well, but its first lines end with àm-me as in our incipit. UET 6/2, 204: 8 begins with the syllabic writing gú úru hul-àm, which would correspond to gù hul in our incipit, but ends differently with gig-bi-š̀̀ mu? ?-un?-x(-x). ${ }^{8}$ Cohen (CLAM 102: 177) and Löhnert (2009, 294-295, 299) reconstruct UET $6 / 2,204$ as the beginning of the section, which would seem to correspond to the sequence of lines in the OB text VS $2,7+13$. However, the first millennium text could have had additions to the litany, and the text in UET 6/2, 204: 8-14 could be an extract from the continuation of the section, as in other extracts on this tablet, which do not necessarily begin with the first lines of the sections. ${ }^{9}$ The incipit listed in our line could perhaps be identical to the catchline of BM 50746: [ ]-e ? eden-ta gù hul [ ]// [ q]i-biti-šú lem-niš? [ ] (note that BM 50746 may also contain the previous section, see note to line $7^{\prime}$ above). ${ }^{10}$ This is also supported by SBH 59, which contains very similar phrases to

8 The reading of the last signs is uncertain. Perhaps read: $x$ à $m$ !- [m] èn!? Cf. collations by Ludwig $(2009,187)$.

9 See CLAM 81-82:e+128-134, 135-136: f+263-268, f+275-277, 154-155: 20-24, 177-178: 25-32, 188: 15-21.

10 Note also that this or a similar section may have also served as part of the Balag úru hul-a-ke ${ }_{4}$ of Gula (CLAM 258: a+90): K. 13984, catchline (CLAM 828): [ ] -e eden-ta [ ]; MLC 2076: r.31' (CLAM 814): TÙN? - e!?(“UN”) [ ]; probably BaM Beih. 2, 17: 64-66, i.e., catchline followed by two syllabic lines with glosses (as in lines 1-3 of the tablet). 
UET 6/2, 204 (gù úru hul-a-na gig-bi DI àm-me), ${ }^{11}$ but not in the beginning of the section (Löhnert 2009, 294-296). The first preserved line of SBH 59 (probably the first or second line of the section) reads: [ ] - ta [ ] // [ (-)b]i-ti-šá [ ] (followed by a litany), which may be identical to the catchline of BM 50746 mentioned above. ${ }^{12}$

9'. This section is not preserved on any of the known manuscripts of the Balag dutu$\operatorname{gin}_{7}$ é-ta, but is known from SBH 52, rev. as part of the Balag̃ úru hul-a-ke $e_{4}$ of Gula and from parallel OB manuscripts: $\mathrm{u}_{4}-\mathrm{ri}_{4}-\mathrm{ri}-\mathrm{gin}{ }_{7}$ te-ga ba-zal (CLAM 258: b+92).

$10^{\prime}$. It is not clear whether the line ends with the sign $\mathrm{E}$ or that there is nothing written at the end, but simply some scratches. The section mu-lu $u_{6}$-di e-lum mu-lu u $u_{6}$-di is not preserved on any of the known manuscripts of the Balag dutu-gin ${ }_{7}$ è-ta (although cf. n. 12 above), but is known from the Balag̃ mu-tin nu-nus dím-ma of Gula (CLAM 226: $a+52$ ). It is also known from the Balag̃ am-e bára an-na-ra ("Chicago catalogue": $6^{\prime}$ and probably SBH 26: r.11'ff., see Gabbay 2007a, 94). Its first and last lines are also preserved in the summary tablet TCL $6,55: 15^{\prime}-16^{\prime}$, probably belonging to the Balag a m-e a maš-a-na (CLAM 162: b+193).

11'. This is an incipit of a section known from the Balag dutu-gin ${ }_{7}$ è-ta (CLAM 102 f.: a+196ff.; Löhnert 2009, 322 ff., 'OB Kirugu n+1'): da m-gàr-ra ba-da-kúr dù $\mathrm{ka}-\mathrm{na} \tilde{\mathrm{g}}-\tilde{g} a \mathrm{a}^{\mathrm{a}}$ al-lù. Note that this section follows the section $\mathrm{mu}-\mathrm{lu} \mathrm{u}_{6}$-di as in our text also in VS 24, 34 and TCL 6, 55:16'-17' (see on 1.10'). The last part of the line in our tablet is very unclear and therefore the readings of the signs are not certain. Note that the sign dumu (instead of dù) is used also in TCL 6, 55: 17' (cf. Löhnert 2009, 332).

12'. This line is not known as a separate section but is rather a summary of the second and third lines of the section beginning with the incipit cited in the previous line (Löhnert 2009, 322, 'OB Kirugu n+1'): úru-ta dam-gàr-ra ba-da-kúr dù ka-nag̃-ǵá al-1ù / mu-lu šìr-ra èš nibruki-ta. It is curious that this is cited here separately (following a dividing line), as if lines $11^{\prime}$ and $12^{\prime}$ represent two different sections.

13'. This incipit is not preserved on any of the known manuscripts of the Balag dutu$\operatorname{gin}_{7}$ è-ta, but may be the incipit of the abbreviated section found in SBH 14: 10-17: šì-sag̃ eden-ta kaš $\breve{4}_{4}-\mathrm{du}_{11}$ ì-gul-e (CLAM 321: a+8-14; Balag̃ am-e bára-anna-ra), although our tablet seems to have dub-sa g and not šì-sa g, and the first part of the sign DÚB rather than $\mathrm{kaš}_{4}$. However, since the tablet SBH 14 probably contains abbreviated sections, it is possible that the first line of the section in the tablet (SBH 14: 10) is not the incipit of the section, and that the incipit had a variant form. In addition, since the section š̀̀r-sa g eden-ta $\mathrm{kas}_{4}-\mathrm{du}_{11} \mathrm{ì}-\mathrm{gul}$-e contains phrases which are possibly to be restored also in a section of the Balag̃ dutu-gin 7 è-ta (Löhnert 2009, 350: 1'-2', 360, ' $O B$ Kirugu $n+2$ '), it is possible that this is actually the incipit of the unknown section (or one of two unknown sections) following the section dam-gàr-ra ba-da-kúr of the Balag̃ dutu-gin 7 è-ta (Löhnert 2009, 346-373, 'OB Kirugu n+2').13

11 Parallel: BM 121074, right column, see Löhnert (2009, 135, n. 488, 296, pl. I).

12 Note that the reverse of SBH 59 (not copied by Reisner) may have contained the section $\mathrm{mu}-1 \mathrm{u} \mathrm{u} \mathrm{u}_{6}$-di e-lum $\mathrm{u}_{6}-\mathrm{di}$, followed by a catchline to the section da m-gà $\mathrm{r}-\mathrm{ra}$ ba da-kúr (Löhnert 2009, 135 and pl. XIV), corresponding to the incipits listed in lines $10^{\prime}-11^{\prime}$ of our text. This may perhaps indicate that $\mathrm{SBH} 59$ is actually a manuscript of the Balag̃ dutu-gin 7 è-ta, despite the variant ḩul-a-na (lines 16'-19' // BM 121074, right col. $14^{\prime}-17^{\prime}$ ) for gú úru hul-àm in UET 6/2, 204: 8 (Löhnert 2009, 299: 1).

13 If so, the many lines in this section which are not found in the corresponding section of the Balag̃ am-e bára-an-na-ra do not necessarily imply that the section was different in both Balag̃s, but rather that SBH 14: 10-17 only offers an extract of it. 
14'.-r.6. These lines are an extract from a section of the Balag dutu-gin 7 è-ta (Löhnert 2009, 354-356: 24'-34', 'OB Kirugu n+2'). If this section is indicated also by the previous line (cf. note to $1.13^{\prime}$ above), it would be curious that a dividing line separates lines $14^{\prime}-$ r. 6 from line $13^{\prime}$, but a similar phenomenon occurs in lines $11^{\prime}-12^{\prime}$ (see note above). Alternatively, it is possible that two unidentified sections (and not only one) followed the section dam-gàr-ra ba-da-kúr of the Balag̃ dutu-gin 7 è-ta (cf. Löhnert 2009, 103, 346 ), the first one beginning with the incipit listed in line $13^{\prime}$ of our text, and the second presented in the extract in lines $14^{\prime}-$ r.6.

Line $17^{\prime}$ seems to differ from the only other manuscript preserving the beginning of the line, BM 35362: $2^{\prime}$, which appears to have: al-DU [ ], but note that the OB manuscript VS

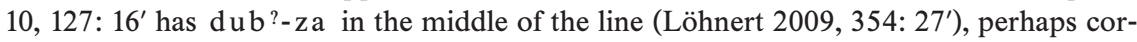
responding to $\mathrm{dub}-\mathrm{s} a \tilde{\mathrm{g}}$ in our text. Some other interesting variants in our text are line r.2: è $\tilde{g}(-) b i(-) d u_{11}-g a-z u$ for è $\tilde{g}$ bí-du $u_{11}-g a-z u$, line r.4: en-nun-gub for i-ni-ingub, line r.5: $\mathrm{su}_{8}$-tuš for bí-tuš and ba-e-tuš, and line r.6: en-na dúb-sig ${ }_{5}^{-}$ ga-ni for è-NI dub-sa 6 -ga-na.

r.7. This incipit, although probably without the doubling of the phrase as in our tablet, is found in other manuscripts of the Balag̃ dutu-gin ${ }_{7}$ è-ta (following the section cited in the previous line of our tablet) (cf. Löhnert 2009, 374: 1, 'OB Kirugu n+3'):14

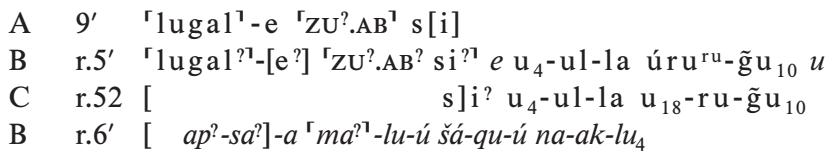

5.8-9. We are unable to identify these incipits. These incipits, as well as the incipit in line r.10, indicate that the gap between 'OB Kirugu n+3' and 'OB Kirugu n+4' (Löhnert 2009, 374-383) most probably consisted of more than one section (cf. already Löhnert 2009, 377).

r.10. This section is not preserved in any of the known manuscripts of the Balag dutu$\operatorname{gin}_{7}$ è-ta, but is known from the Balag̃ a gal-gal buru ${ }_{14} \mathrm{su}-\mathrm{su}$ of Nergal (CLAM $506 \mathrm{ff} .: \mathrm{a}+91 \mathrm{ff}$.), where it contains a Nergal litany (which may not have been the case in the Balag̃ dutu-gin ${ }_{7}$ è-ta). The incipit is preserved in two manuscripts of the Balag a galgal buru ${ }_{14} \mathrm{su}-\mathrm{su}$ (note that in text I, the performative indication $a$ appears in the same place as in our line): 15

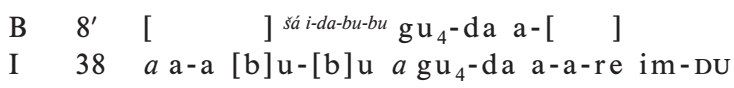

r.11. This section is preserved in SBH 40 obv., belonging to the Balag dutu-gin è-ta:16 [a-za-lu-lu a]-za-1u-lu // a-hu-lap ni-ši (SBH 40: 1; Löhnert 2009, 379, 'OB Kirugu $n+4^{\prime}$; cf. also CLAM 132: $\left.\mathrm{c}+164\right) .{ }^{17}$

r.12-14. The first two lines seem to be glosses and notations related to the performance and not part of the text (see below). Rev. 14 contains the first line of the long god litany

14 Sigla: $\mathrm{A}=\mathrm{BM} 35362 ; \mathrm{B}=\mathrm{CTMMA} 2,3 ; \mathrm{C}=4 \mathrm{R}^{2}, 11$.

15 Sigla according to CLAM 500: B = BM 55474 (CLAM 833); $\mathrm{I}=\mathrm{SBH} 9$.

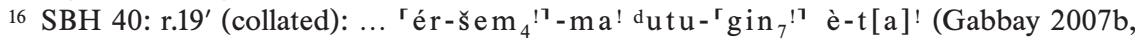
233, pl. 10; Löhnert 2009, 151).

17 Note that the fragment in the right corner copied by Reisner, does not belong here (Gabbay 2007b, 230, n. 56; Löhnert 2009, 151). 
known from several Balag̃s, usually as their last section..$^{18}$ It is not certain whether the sign AN before ${ }^{\mathrm{d}} \mathrm{uras}$ is part of the text or part of a performative gloss (i.e., $a_{4}{ }^{\mathrm{d} u r a s ̌}$ ). For the writing an duraš (as opposed to an uraš), see BaM Beih. 2, 22: 5' and the OB text VS 2, 11: r.2 (CLAM 280: e+173, 355: a+189).

r.15. This is the standard concluding line of Balag̃s in the first millennium, ${ }^{19}$ but the temple name is not expected to be Eg̃išnugal in the Balag ${ }^{\mathrm{d}} \mathrm{utu}-\mathrm{gin}{ }_{7}$ è-ta, which is an Enlil composition, and Ekur would have been expected. The line, most probably to be restored with é-kur, is preserved at the end of the OB text PBS 1/1, 8 (CLAM 107: d+273; Löhnert 2009, 165, pl. III): šùd-bi še-eb [é-kur]-r[a-ta] ki na-an-gi $i_{4}-g i_{4}-r$ [a] The mention of Eg̃išnugal reflects a Late Babylonian local tradition of the city of Ur, which altered the Enlil/Nippur theology of this line to Sîn and his temple Eg̃išnugal (Gabbay, forthcoming a). The same occurs in BM 113940: r.4 edited below. The sign ŠÈM after šù du is not expected. ${ }^{20}$ The sign which is usually found in the first millennium formula of this line is NE (probably: šùdu-dè).

r.16-18. This is the incipit of the Eršema associated with the Balag̃ dutu-gin 7 è-ta (see above). The first line is preserved in TCL 6, 56:1 (Gabbay 2007b, 231; note that the performative indications are very similar to our text): [( )] [ù-1i-1i] ${ }^{\top} \mathrm{en}^{\top} \mathrm{zu} u^{\mathrm{r}} \mathrm{sá}^{\top}$ mar-mar an-nu-u u mi-hir ${ }^{\top} a_{4}^{\top}{ }^{\top} \mathrm{en}^{\top} \mathrm{zu} u^{\top} \mathrm{en}^{\top} \mathrm{zu} u^{\mathrm{\Gamma}} \mathrm{sá}^{\top} \mathrm{mar}-\mathrm{mar}$

If the end of line r.17 of our text indeed has $\mathrm{mu}-[1 \mathrm{u}]$, perhaps it reflects the formula mu-lu ta-zu mu-un-zu, often appearing in Emesal texts, especially in the Balag en zu sá mar-mar mu-lu ta-zu mu-un-zu (CLAM 402: [1]). Note, however, that according to TCL 5, 56: 1, there is no indication for this phrase in the Eršema.

r.19. This line could have preserved the incipit of a second part of the Eršema or an extract from this section, as is the case in BM 113940 (see below), or the incipit of the first section of another Balag̃ (perhaps Balag̃ $u_{4}-\mathrm{dam}$ ki àm-ús, which follows Balag̃ dutu $\operatorname{gin}_{7}$ è-ta according to the canonical sequence from Nineveh).

18 Cf. CLAM 134: f+227, 234; c+251, 280: e+174, 355: a+189, 303: c+125, 389: b+129, 420: a+47, 491: f+207, BaM Beih. 2, 22: 5'.

19 Note the recent interpretation suggested by Löhnert $(2009,24-29)$ for the OB formula: šù d-bi še-eb TN-ta $\mathrm{ki}-\mathrm{na}$ dig̃ $\mathrm{gi}_{4}-\mathrm{gi}_{4}$-ra. In any case, in the first millennium the phrase was understood differently, as indicated by the use of the signs NE and en (and not $\mathrm{na}$ and $\mathrm{AN}$ ), and by the Akkadian translation of this line preserved in two tablets, BM 38756: 10' (i-na ik-ri-bi li-b[it-ti ...) and K.5160+ r.iii 28' ([ina ikribi l]i-bit-ti É.MIN ana áš-ri-š [á? ...]), which may reflect: ina ikribi libitti TN ana ašriša litūr (Gabbay 2007b, 201, 301). The fact that the line includes performative indications would seem to indicate that (at least in the first millennium, but likely also earlier) it was not a subscript (cf. Löhnert 2009, 27-29), but rather a concluding line which was part of the performed composition (performative indications are found with this line also in the "Converse tablet" r.30, see note to BM 113940 r.4 below, and SBH 23 r.26). This is further supported by the Akkadian translation to this line in the two tablets mentioned above. The separation from the previous section by a dividing line was perhaps for ritual reasons, e.g. change of place of performance for this line. Note the similar format of many first millennium Eršemas where a modal clause ("Do not abandon your city ...") separated by dividing lines ends the compositions (see Gabbay 2007b, 16-17).

20 Could this be a writing indicating $\breve{s u}_{12}$-ù b (cf. šùd-bi in OB texts, Löhnert 2009, 24-29)? Or could this be a musical instruction referring to the Eršema that follows (to be performed with the ŠÈM = halhallatu $)$ ? 


\section{BM 113940}

The tablet BM 113940 contains incipits and extracts of the sequence of sections of the Balag ukkin-ta eš-bar til-1a, including the Eršema ur-sa g a-ma-ru hu-luh-ha, known to be paired with this Balag̃ according to the Nineveh kalutu catalogue ${ }^{21}$ and according to manuscripts of this Balag̃ which contain this Eršema or a catchline to it. ${ }^{22}$

\section{Transliteration}

obv.

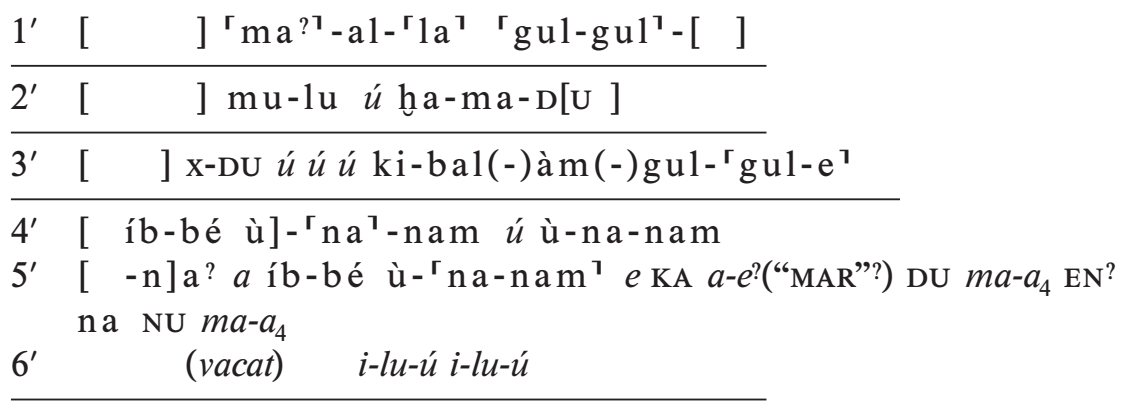

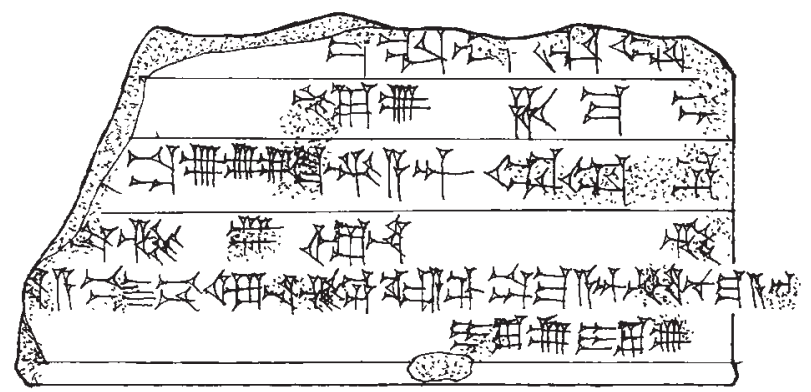

Fig. 3: BM 113940 obv.

22 "Converse tablet" and K. 11211 (Lambert 1971, 346, 352; Gabbay 2007b, 349-350). 


\title{
bottom
}

rev.

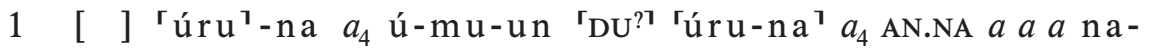

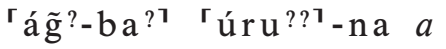

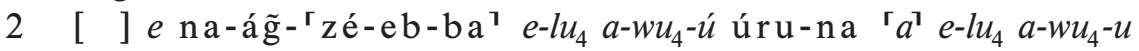

3 [ umun-ra mu-lu sís]kur-ra-ke ${ }_{4}{ }^{\top} e^{\top}$ sískur dè-ra$\mathrm{ab}$-bé $a$

4 [ ك̌ùdu š̀̀M? še-eb] 'é'-g̃ iš-nu ${ }_{11}-g a l$ ki NE-en-gi ${ }_{4}-g i_{4}$

5 [ ur-sag̃ a-ma-ru] 'huu-luh-ḩa' me-lám huuša-ri-a $e$

6 [ ] úru ki-bé gi $\mathrm{i}_{4}$-a (ras.) $a$-wu $u_{4}$-u za-e umun-bi NE-g̃en $e$

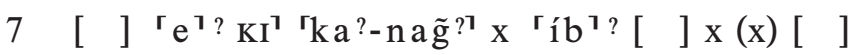

rest broken

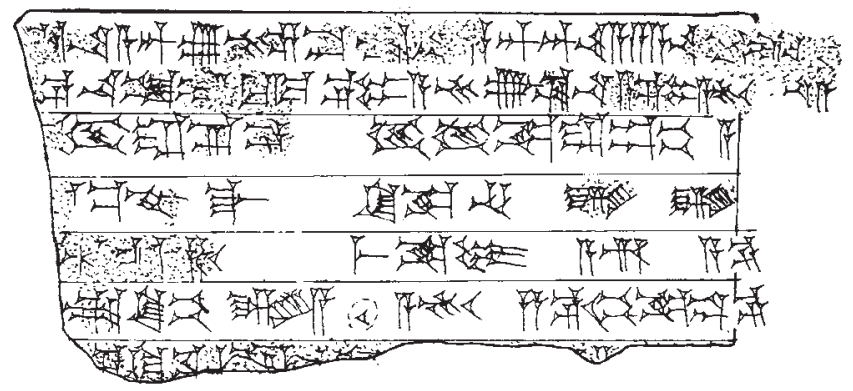

Fig. 4: BM 113940 rev.

\begin{abstract}
Notes
$\mathbf{1}^{\prime}$. Since the incipit in line $2^{\prime}$ is identified as the incipit of a section of the Bala $\tilde{g}$ ukkin-ta e š-bar til-1a (CLAM 485: c+83, see note to line 2'), the incipit in this line would have been expected to correspond to the incipit of the previous section of the same Balag̃: a šeg ${ }_{10}$-gi $i_{4}$-a-ni-ta kur al-gul-gul-e (CLAM 484: c+65), but unless ' $\mathrm{ma}^{\text {? }}-\mathrm{al}-{ }^{\mathrm{r}} \mathrm{la} \mathrm{a}^{\mathrm{T}}-\mathrm{gul}-\mathrm{gul}-\left[\mathrm{e}^{\text {? }}\right]$ in our line is a variant for al-gul-gul-e, this would not correspond to the expected incipit. Note that the incipit of the section before this also has a similar phrase (CLAM 482: c+43).23
\end{abstract}

${ }^{23}$ Cohen's restoration is probably based on the last three lines of the section, which seem to correspond to the first lines (CLAM 484: c+62-64), and on an OB section with the incipit: a-ma-ru na-nam kur al-gul-gul (CLAM 277: b+94, cf. 302: [a+99]). 
$2^{\prime}$. This is the incipit of a section known from the Balag $\tilde{g}$ kkin-ta es bar til-la: [ ì-gub]-bé-en mu-lu ha-ma-gub (CLAM 485: c+83).

$3^{\prime}$. This is the incipit of a section known from the Balag ukkin-ta eš bar til-1a: g̃uruš kala-ga šu-du 7 -g̃á ki-bal-a gul-gul-[ ] (CLAM 486: d+108). The writing DU in our line may reflect $\tilde{g}$ en, syllabically corresponding to $\tilde{\mathrm{g}}$ á (or $\tilde{\mathrm{g}} \mathrm{e}_{26}$ ) in the preserved part of the incipit of this section of the Balag according to SBH 12: 10'. According to the catchline of BL 158+K.19695, this sign seems to be omitted: g̃uruš kala-ga šu du $\mathrm{k}[\mathrm{i}]$.

$4^{\prime}-6^{\prime}$. These lines correspond to the incipit of a section of the Balag̃ ukkin-ta eš-bar til-1a (CLAM 487: d+137, and the new manuscript BM 113918: 1-2 from LB Ur, see score transliteration below). This section follows the section of this Balag quoted in the previous line (see note to line $3^{\prime}$ ). For the performative indications in Lines $5^{\prime}-6^{\prime}$, see below. The repetition of ù-na-nam in the second part of the line is indicated by other manuscripts preserving this line (contra Lambert 1971, 344: 1, CLAM 487: d+137), and by the Akkadian translation to the line: kadriš kadrišma, the second word previously read as PI SAG MA, see Lambert (1971, 348: "The pi sag ma suggests nothing Sumerian, but it could be Akkadian (pi-ris-ma 'it is a section'? a kind of gloss?)." As noted, this should actually be read: kád!-riš-ma, corresponding to ù-n a-nam (an alternative Akkadian translation is also offered by most of the manuscripts). Following is a score transliteration of the sources for this line: ${ }^{24}$

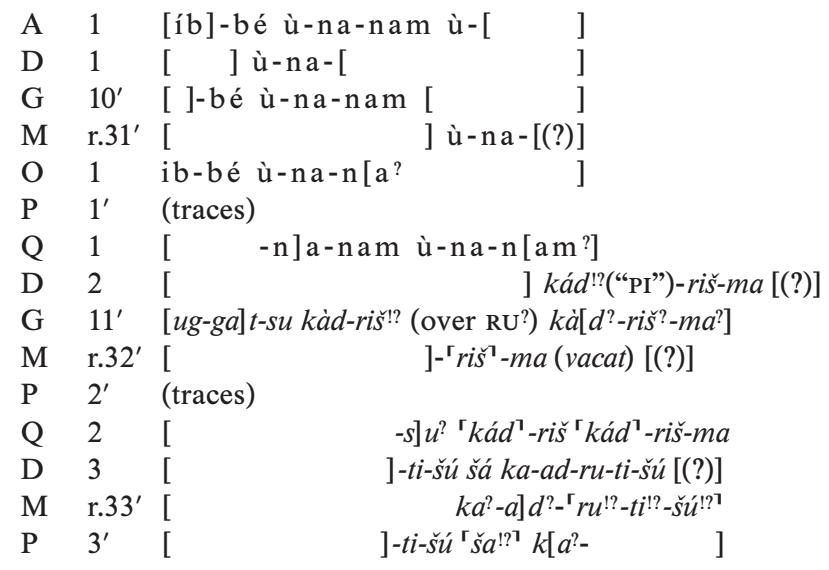

r.1-2. These lines correspond to the incipit of a section of the Balag̃ ukkin-ta eš-bar til-1a (probably following the incipit quoted in the previous lines, CLAM 490: $f+205$ and BM 113918, catchline). The incipit is also preserved with performative indications in the

However, what is listed as the second line of the section in CLAM 482: c+44, is actually the first line on the top of the tablet K.3238 (BL 158)+K.19695, thus likely to be the first line of the section, and therefore the incipit, or at least the first part of the incipit, should probably be restored differently.

24 Sigla according to CLAM 479, except for BM 113918: A = 81-2-4, 303 (CLAM 821); $\mathrm{D}=$ "Converse tablet" (Lambert 1971, 340); G = K.10303 (Lambert 1971, 349; collated); $\mathrm{M}=\mathrm{SBH} 12 ; \mathrm{O}=\mathrm{VS}$ 10, 154 (OB); $\mathrm{P}=\mathrm{K} .5180$ (CLAM 832; collated; parallel text); $\mathrm{Q}=\mathrm{BM} 113918$ (unpublished). 
“Converse tablet” (r.6): umun ${ }_{e}{ }_{e}$ úru-ni-a ${ }^{a}$ na-a-ág-zé-eb ba-an-tar-re e e naá g̃ -zé-eb-ba ana šìr-ru (Lambert 1971, 342).

r.3. This is the incipit of a section of the Balag̃ ukkin-ta eš bar til-1a (CLAM 491: $\mathrm{f}+204)$. The incipit is preserved with performative indications in the "Converse tablet" (r.17'): MIN $u$ umun-ra mu-lu sískur-ra-ke ${ }_{4} e$ sískur dè-ra-ab-bé (Lambert 1971, 343).

r.4. This is the standard concluding line of Balag̃s, known also from the Bala $\tilde{g}$ ukkin-ta eš bar til-1a (CLAM 492: $\mathrm{f}+248$ ). The line is preserved with performative indications in the "Converse tablet" (r.30): [ ̌̌ ù]d-dè $e$ še-eb $e$ é-zi-da-ta $a$ ki $i$ NEen-gi $\mathrm{i}_{4}-\mathrm{gi}_{4} i$ (Lambert 1971, 343). For the mention of the Eg̃išnugal instead of Ezida, cf. BM 113931: r.15 with note above.

r.5. This is the incipit of the Eršema associated with the Balag̃ ukkin-ta eš bar til-1a (see above). The "Converse tablet" (line r.32) preserves the incipit with performative indications as the catchline (Lambert 1971, 343, 346: 32; Gabbay 2007b, 349): [ur]-sag̃ a-ma-ru hu-luh-ḩa MIN me-lám ḩuš ní ri e-e TA a e-e a an-nu-u a an$n u-u{ }^{\top}$ ana $\mathrm{DU}_{12}-r u^{\text {?' }}$. The end of the incipit ([ ] ní $\mathrm{ri}$ ) is also preserved in K.11211: 10' (Lambert 1971, 352; Gabbay 2007b, 350). Note the variant a ri-a for ní ri in the incipit of the Eršema in our tablet.

r.6-7. It is not certain to what these lines refer. It is possible that they refer to incipits of sections of the Eršema, which are not preserved. The second part of line 6 is preserved as part of the formula za-e umun-bi NE-g̃en na-an-šub-bé-en dè-ra-ab-bé $a-r a-z u$ dè-ra-ab-bé, followed by two more lines, ending supplication sections found in other Emesal prayers. ${ }^{25}$

\section{Performative Indications in BM 113931 and BM $113940^{26}$}

\section{BM 113931}

Left margin: KA-SED $(3,4,6,9 ;$ r.7-9, 11, 12) KA-ZI $(2,5,8,10-14 ; \mathrm{r} .10,15,16,17)$

Face: $\quad a(5,9,13,14 ;$ r. $5,5,7-10,17) \quad e(12,12,13,13,14,14,15,16,17 ;$ r.7, 10) $a-a$ AN.NA $a(8)$ $a-e(\mathrm{r} .13) \quad \dot{u}(5,6 ; \mathrm{r} .4,16,17)$

a an-nu-ú $(2,3,4) \quad$ ia- $a(\mathrm{r} .2,3)$

$a-w u_{4}-u ́(\mathrm{r} .12) \quad$ NI-DI $e u ́$ DI $e$ NI-DI $e(\mathrm{r} .12,13)$

25 See Löhnert (2009, 192: 122-124; 254-256; CLAM 100: 125-127, 136: f+275-277, 326: e+150-152, 390-391: c+167-169, 472: a+75-77, 530: 99-101, SBH 11: [r.21'-23'], BL 9a+BL 73: r.45-47 (Eršema nir-g̃ál lú è-NE: a+81, Gabbay 2007b, 391-401).

26 The ordering of performative indications follows the same principles as the table in Mirelman (2010, 248-257). Repeated indications in the same line are shown by simple repetition of the attestation. 
BM 113940

Face: $\quad a(5 ; \mathrm{r} .1,2,3)$

$a-w u_{4}-u$ (r. 2, 6)

$a-w u_{4}-u$ (r.2)

$a_{4}$ AN.NA $a-a-a$ (r.1)

$a_{4}$ ú-mu-un 'DU?' (r.1) $e(5 ; \mathrm{r} .3,5,6)$

ú $(2,4)$

ú-ú-ú (3)

i-lu-ú i-lu-ú (6)

KA $a e^{?}$ DU $m a-a_{4} \mathrm{EN}^{?}$ na NU $m a-a_{4}(5)$

Isolated performative vowels $a, e, \dot{u}$ in both tablets (and one $i$ in BM 113931) are well known from other LB Balag̃s and Eršsemas, and were recently collected by Mirelman (2010, 248-257). Generally, the distribution of performative vowels in these tablets follows what is known from other Emesal prayers of this period. The most common single vowels in the corpus are, in descending popularity, /a/, /e/, /u/ and /i/. The vowel /i/ is rare, as it is in our texts. /a/ and /e/ are the most common isolated vowels, as they are here. The isolated vowel $u$ is used instead of $u$ in our texts; this is unusual in comparison with the rest of the corpus where $u$ is more commonly attested. The sequence $a-e$ is well attested, see Mirelman (2010,

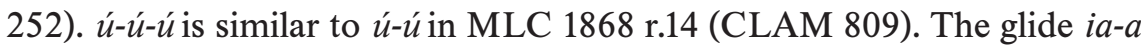
(BM 113931 r.2, 3) has no direct parallel with other LB performative indications. However, sequences such as $(e)-i a-(a)$ are featured in at least one identified OB text with performative indications (Mirelman/Sallaberger 2010, 185-186). We follow Krecher $(1967,277)$, in understanding the performative indications A.AN and $\mathrm{MU}$ (in the sequence $a-\mathrm{MU}-u$ ) in our texts, and in many other texts (see references by Mirelman 2010, 248-257), according to their LB values $a_{4}$ and $w u_{4}$ (i.e., $\left.a-w u_{4}-u_{(2)}\right)$. In addition, the sequence $m a-a_{4}$ appearing twice in BM 113940: $5^{\prime}$ and in parallels (see Mirelman $2010,254,257)$ may have actually indicated the LB value $w a_{6}-a_{4}$.

Mirelman (2010, 244-245) suggested an interpretation of isolated performative vowels and vowel-sequences as mnemonic solmisation sequences, where relative pitch is indicated by vowel quality. In this interpretation, the vowel indications refer to the relative pitch in which the words or phrases they relate to are to be performed. The relative pitch sequence is (high to low) generally /i/, /e/, /a/, /o/, /u/.27 The vowels /e/, $/ \mathrm{a} / \mathrm{and} / \mathrm{o} /$ are not in strict sequence, but /i/ is generally highest and $/ \mathrm{u} /$ generally lowest. Thus, /i/ would indicate a high pitch singing and /u/ would indicate a low pitch singing.

$a n-n u-u ́$ is a well known indication meaning "high, of singing" (Lambert 1971, 344; Mirelman 2010, 246-257). The forms in our texts (written an-

27 However, there is no evidence to suggest that /o/ is represented in LB performative indications. 
$n u-u ́$ and AN.NA), preceded by $a, a_{4}$, or $a$ - $a$, are known elsewhere (see Mirelman 2010, 248, 253, 255). We understand these indications to refer to an additional higher pitch than the regular relative pitch of the vowel /a/ within the sequence $/ \mathrm{i} /, / \mathrm{e} /, / \mathrm{a} /, / \mathrm{o} /, / \mathrm{u} / .^{28}$

The sequence $e-l u_{4} a-w u_{4}-\dot{u}$ (BM 113940 r.2, twice) also occurs (with variant spellings) in TCL 15, 11:3,10,20-34. $e$-lu is probably an exclamation, similar to ilû (see Mirelman 2010, 251-257). The repeated sequence ilû ilû (BM 113940: 6) occurs also elsewhere (see Mirelman 2010, 255-257).

The sequence NI-DI $e u$ DI $e$ NI-DI $e$ is repeated exactly in two consecutive lines (BM 113931 r. 12-13). This is unusual for such a long sequence, and it is not clear whether this is actually a performative indication or part of the text. The element NI-DI (with NI read as ì?) can perhaps be related to TCL 6, 55: 15': an $u$ ki-a ú i-di mi-hir ú-ú i-di x; cf. also CTMMA 2, 3: 12 , which has $\mathrm{x}$ (ras.) DI in the left margin. ${ }^{29}$

The sign DU is found as a performative indication in BM 133940: 5 and probably also r.1. This may perhaps be compared to $a$ DU in the "Converse tablet": r.5 (cf. Mirelman 2010, 257). Perhaps Du here stands for kânu, "to be firm, remain, last," indicating a sustained pitch on the preceding vowel (cf. also the indication NU TIL in other tablets, referring also to a performance without interruption, see appendix below). In BM 113940: 5, the first part of the line may indicate sustained vocal notes on the relative pitches indicated by the vowels $a$ and $e$. In line r.1, the sign DU (if read correctly) may indicate that the relative pitch $a_{4}$ with the word /umun/ in the line, is to be extraordinarily sustained.

The performative indications in the second part of BM 113940: 5 are enigmatic. EN may refer to $a d i$, "until", i.e., a performance of $m a_{4}-a$ up to a certain point (na? perhaps referring to the element na in ù-na-nam of the incipit?), after which it is not (NU) to be performed. $\mathrm{EN}=$ adi here may be compared to TA, perhaps standing for ištu, "from", which occurs in vowel sequences in other tablets as well, see references listed by Mirelman $(2010,254,255-257) .^{30}$

28 W. Sallaberger (personal communication) suggested to understand an- nu- $u_{(2)}$ and an-na here as interjections, corresponding to the vowels following them.

29 Another possibility is that $n i-d i$ stands for $n \bar{l} d u$, known also from the musical term nìd qabli, but here referring to something else (cf. Mirelman 2010, 246). Since $n \bar{l} d u$ may be written with the sign ŠUB, perhaps $n i$-di here is comparable to šUB (at times followed by a vowel), which appears in other tablets containing Emesal prayers, see references by Mirelman $(2010,250,257)$. If so, DI standing alone in lines r.12-13 of our text would have to be interpreted differently.

30 Note that $a$-di follows a performative indication in an incipit of a section of an Emesal prayer also in BaM Beih. 2, 15: 3' (cf. Gabbay 2007b, 111). 
BM 113931 contains the performative indications KA ZI and KA SED before each section. ${ }^{31}$ We know of no parallel to this. ${ }^{32}$ Perhaps this refers to the voice $(\mathrm{KA}=\mathrm{GU}=$ rigmu $)$ in which the sections should be performed, indicating a high or raised voice $(\mathrm{ZI}=t e b \hat{u})$, and a low or quiet voice $(\mathrm{SED}=$ pašăhu, pašhu $) . \mathrm{ZI}=$ teb $\hat{u}$ (or a related adjectival form) has the general meaning "rise, pulsate." SED = pašăhu (or a related adjectival form) has the general meaning "relax, soothe." The juxtaposition of KA SED with ann $\hat{u}$ "high, of singing" in BM 113931: 4 would suggest that the opposition between KA ZI and KA SED is not between high and low pitch, but between other vocal qualities. The opposition of ZI and SED may signify "loud" ( $\mathrm{ZI}=$ tebû, "raised") vs. "quiet" ( $\operatorname{SED}=$ pašhu $u$, literally: "calm").

But perhaps this apposition is more complex. An application of $\mathrm{ZI}=$

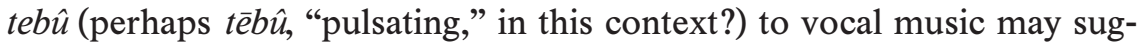
gest vocal tremolo or 'vibrato', meaning a constant, slight pulsation or oscillation in pitch. As observed by Nathan Wasserman, pašăhu (= SED) can also have a specific meaning "to make flat" (particularly in relation to "ironing out wrinkles" in cloth). ${ }^{33}$ Thus, we might guess that the opposi-

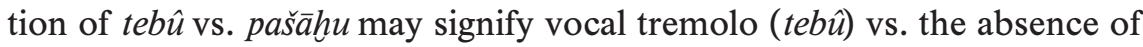
tremolo (pašāhu).

Both KA and ZI are used in other LB performative indications (although not together). KU ZI is used as a musical indication in BaM Beih. 2, 17: 3, 66 (left margin), 22: 2' (left margin), 38: 4', and perhaps also TCL 6, 55: $20^{\prime}$ (left margin). ${ }^{34} \mathrm{KA}$ appears in the sequence KA $i$ in CT 42, 1: 41 (left margin) and KA $a$ in CT 42, 1 r. 18 (left margin), and probably also KA $a-e$ in BM 113940: $5^{\prime}$ (see above). In these cases, it seems probable that the vowels following KA are additional to whatever is meant by KA. The appearance of KA followed by a vowel in CT 42, 1 and BM 113940: 5', and the appearance of the term KU ZI in the Uruk texts mentioned above, all occur at structurally important sections of the text. In all cases, the indication appears at the first or second line of a new section, indicated by a preceding dividing line, usually at the left margin before the beginning of

\footnotetext{
${ }^{31}$ It is likely that these performative indications were also found in the unpreserved left side of BM 113940.

32 Cf. Erimhuš VI 43: KA.s[ED $\left.]^{\mathrm{s}}\right]_{\text {i-id }} g\left[a^{?}\right]-\mathrm{x}-[\mathrm{x}]$ (MSL 17, 82).

33 We thank N. Wasserman for making available to us a preliminary version of his discussion of pašăhu from a forthcoming study.

34 This would be quite homonymous to the reading GÙ ZI.
} 
the line (as in our text). ${ }^{35}$ Thus, these indications, together with KA ZI and KA SED, may apply to a whole section, as it clearly does in BM 113931.

It is possible that $\mathrm{ZI}$ is related to Old Babylonian references to $\mathrm{zi}$ in a musical context, although their interpretation is problematic. ${ }^{36}$ The musical term zi(-zi) is paired with either g̃á-g̃á or šú-šú in the context of vocal or instrumental performance (Shehata 2009, 351-354). All three terms occur in sequence in a musical section of Proto-Lú (MSL 12, 55: 625-627). zi-zi and šú-šú probably refer to instrumental performance in Šulgi B 160 (Krispijn 1990, 1): zi-zi-i šú-šú-ba g̃es mu-e-hurhuur, and Šulgi C ii 78' (cf. Krispijn 1990, 6): zi-zi-i šú-šú-bi in$\mathrm{ga}-\mathrm{zu}$. The same pair also occurs with reference to the tigi and za-amza-am in Šulgi E 34 (Krispijn 1990, 6): zi-zi-i šú-šú tigi za-amza-am-ma-ka ki bí-zu-zu-a. Although these references seem to deal with instrumental performances, it is possible that some interchange between instrumental and vocal terminology is to be expected. A probable usage of the term zi-zi with reference to vocal performance ( $\breve{i ̀ r}$ ), this time paried with g̃á-gá, occurs in Dumuzi-Inana J (Alster 1985, 223: 29'): e-ne-ne šìr im-zi-zi-ne šìr im-g̃á-g̃á-ne. ${ }^{37}$

\section{Appendix: \\ Additions to the Corpus of Late Babylonian Texts with Performative Indications}

Nine texts with performative indications can now be added to the 47 which have already been listed by Mirelman (2010, 258-260). Almost all of the performative indications in these newly identified texts are already

35 The indication appears in the middle of the line only in BaM Beih. 2, 17: 3 and BaM Beih. 2, 38: 4', and at the end of the incipit in BM 113940: 5'. The indications in CT 42, 1: 41 and r.18 occur in the beginning of sections (CLAM 386-387: a+40, a+74), and so do those in BaM Beih. 2, 17: 3 and 66 (CLAM 256: a+29, second line of the section, 258: a+90). The indication in BaM Beih. 2, 22: $2^{\prime}$ probably occurs at the beginning of the last section of a Balag (the tablet probably had an indication of skipped lines in its broken part). The indication in BaM Beih. 2, 38: 4' occurs in the second line of a section (// CTMMA 2, 8: r.12'). The indication in TCL 6, 55:20' occurs in the first line of a section (CLAM 164: c+247). The indication in BM 113940:5' occurs with the incipit of a section.

36 Note that ZI (= nasāhu $)$ also appears as a technical term for the tuning of stringed instruments (cf. Krispijn 1990, 5-6), but it is unlikely that it is connected to $\mathrm{ZI}$ in our text.

37 Alster $(1985,219,221,223-224: 36-37)$ suggests that the text itself refers to the performance of an Eršema, although this is not possible to determine considering the fragmentary nature of the text. 
well known (see list below). The use of the vowels $a$ and $e$ directly preceding half lines is an entirely typical usage of performative indications. BM 83026 is particularly interesting for its use of more complex performative indications. The use of šú on the left margin of BM 83026 is known from several other texts, alone and in combination with other signs, see Mirelman (2010, 250). NU-TIL (MIN) $e$ in BM 83026: r.5'-6' must be interpreted as a variant (with the vowel $e$ ) of NU-TIL $a$, which appears on the left margin of SBH 1 r.19' (read as NU-BAD-A in Mirelman 2010, 250). These vowels are likely to be performative indications; such vowels are appended to other marginal performative indications, such as KA, ŠÚ and ŠUB, see Mirelman (2010, 249-250). A reading of NU-TIL as singing "without stopping" may refer to a continuous performance without interruption. ${ }^{38}$

Following is a list of the new texts containing performative indications:

BM 39367: Duplicates CLAM 53: 67-78 (Balag̃ abzu pe-el-lá-àm). There is a broken sign on $7^{\prime}$, left margin, which is probably a performative indication.

BM 78401: Unidentified bilingual Emesal fragment related to Enki/Ea. Some lines parallel Kramer (1985, 116ff.). The performative indication $a$ is used in the middle of lines 7, 9, 12 and 14 , and $e$ is used in the same way in line 5.

BM 82937: Unidentified bilingual Emesal fragment concerning a goddess. Line obv.(?) $5^{\prime}-8^{\prime}$ parallel Cohen $(1981,64)$, no. 79: 34-35. Obv.(?) $3^{\prime}$ has an $a$ sign on the left margin. Rev.(?) $10^{\prime}$ has a broken sign on the left margin which is probably a performative indication.

BM 83026: Obv. parallels Cohen (1981, 113-114) no. 1.2: 19-30'; CLAM 227-228: a+93-104, 328: f+184-195; Gabbay (2007b, 443 and 568-569; Balag̃ section/Eršema dilmunki nig̃in-na). Line $2^{\prime}$ has a broken sign on the left margin, and line $8^{\prime}$ has a clear šú on the left margin. R.1' has broken signs on the left margin (perhaps $e$ x šú). R.5' $-6^{\prime}$ and $13^{\prime}$, left margin: NU-TIL, r.6': MIN E.

BM 113931: (edited above)

BM 113932: From LB Ur. Obv. contains an Enki-Marduk litany. The first lines of the reverse duplicate VS 24,27 . The performative indication $a$ directly precedes the second half-line in $16^{\prime}$ and $17^{\prime}$, and r. $7^{\prime}, 9^{\prime}, 11^{\prime}, 13^{\prime}, 15^{\prime}$.

BM 113940: (edited above)

BM 114010: From LB Ur (edition: Gabbay, forthcoming b). The vowel $u$, probably to be understood as a performative indication, follows the exclamation e-1a-1u at the end of line r.8

BM 114079: From LB Ur. Duplicates CLAM 707-709: a+61-78 (Black 1985, 22-23: 154-171). The performative indications $e$ in lines $6^{\prime}-8^{\prime}, \mathrm{r} .2^{\prime}-3^{\prime}$, and $a$ in r.1, directly precede the second half line.

38 Note Cohen (1981, 30) no. 29: 22 (Gabbay 2007b, 307; Eršema nam-mu-un-šubbé-en): šìr-re nu-ti-le ba-n[i i- ] // și-ri-ih la qa-te-e ${ }^{\mathrm{r}}$ tas̆$^{\text {? }}$-[ku-na? ] "You [set?] a wail that is unending!" 


\section{References}

Alster, B. (1985): Geštinanna as Singer and the Chorus of Uruk and Zabalam: UET 6/1, 22, JCS 37, 219-228

Ambos, C. (2004): Mesopotamische Baurituale aus dem 1. Jahrtausend v.Chr. Dresden Black, J. A. (1985): A-še-er $\mathrm{Gi}_{6}$-ta, a Balag of Inana, ASJ 7, 12-87

Cohen, M. E. (1981): Sumerian Hymnology: The Eršemma. HUCA Supp. 2. Cincinnati Gabbay, U. (2007a): A Neo-Babylonian Catalogue of Balag̃ Tablets in the Oriental Institute of Chicago, ZA 97, 86-97

- (2007b): The Sumero-Akkadian Prayer "Eršema": A Philological and Religious Analysis. PhD Dissertation, Hebrew University, Jerusalem

- (forthcoming a): The Performance of Emesal Prayers within the Regular Temple Cult of Ancient Mesopotamia: Content and Ritual Setting, in: Tempel im Alten Orient. Colloquien der Deutschen Orient-Gesellschaft 7. Wiesbaden

- (forthcoming b): Lamentful Proverbs or Proverbial Laments? Intertextual Connections between Sumerian Proverbs and Emesal Laments, JCS

Geller, M. J. (2005): Catalogue of Late Babylonian Ur Texts Excavated by Hall, Kaskal 2, 97-100

Hall, H. R. (1923): Ur and Eridu: The British Museum Excavations of 1919, Journal of Egyptian Archaeology 9, 177-195

- (1930): A Season's Work at Ur, Al-‘Ubaid, Abu Shahrain (Eridu) and Elsewhere. London

Jursa, M. (2005): Neo-Babylonian Legal and Administrative Documents: Typology, Contents and Archives. Guides to the Mesopotamian Textual Record 1. Münster

Kramer, S. N. (1985): BM 86535: A Large Extract of a Diversified Balag Composition, in: J.-M. Durand/J.-R. Kupper (eds.), Miscellanea Babyloniaca: Mélanges offerts à Maurice Birot. Paris, 115-135

Krecher, J. (1967): Die sumerischen Texte in "syllabischer" Orthographie, WO 4, 252-277

Krispijn, Th. J. H. (1990): Beiträge zur altorientalischen Musikforschung 1. Šulgi und die Musik, Akkadica 70, 1-27

Linssen, M. J. H. (2004): The Cults of Uruk and Babylon: The Temple Ritual Texts as Evidence for Hellenistic Cult Practice. Cuneiform Monographs 25. Leiden/Boston

Löhnert, A. (2009): “Wie die Sonne tritt heraus!”. Eine Klage zum Auszug Enlils mit einer Untersuchung zu Komposition und Tradition sumerischer Klagelieder in altbabylonischer Zeit. AOAT 365. Münster

Ludwig, M.-C. (2009): Literarische Texte aus Ur. Kollationen und Kommentare zu UET 6/1-2. UAVA 9. Berlin/New York

Maul, S. M. (1994): Zukunftsbewältigung. Eine Untersuchung altorientalischen Denkens anhand der babylonisch-assyrischen Löserituale (Namburbi). BaF 18. Mainz

- (2000): Die Frühjahrsfeierlichkeiten in Aššur, in: A. R. George/I. L. Finkel (eds.), Wisdom, Gods and Literature. Studies in Assyriology in Honour of W. G. Lambert. Winona Lake, $389-420$

Mirelman, S. (2010): Performative Indications in Late Babylonian Texts, in: R. Pruzsinszky/D. Shehata (eds.), Musiker und Tradierung. Studien zur Rolle von Musikern bei der Verschriftlichung und Tradierung von literarischen Werken. Wiener Offene Orientalistik 8. Vienna, 241-264

Mirelman, S./W. Sallaberger (2010): The Performance of a Sumerian Wedding Song (CT 58, 12), ZA 100, 177-196 
Shehata, D. (2009): Musiker und ihr vokales Repertoire. Untersuchungen zu Inhalt und Organisation von Musikerberufen und Liedgattungen in altbabylonischer Zeit. Göttinger Beiträge zum Alten Orient 3. Göttingen

Wilcke, C. (1976): Kollationen zu den sumerischen literarischen Texten aus Nippur in der Hilprecht-Sammlung Jena. Abh. d. Sächs. Akad. d. Wiss. zu Leipzig, Philol.-hist. Kl. 65/4. Berlin 